\title{
ライフスタイルの変更を支援するライフ サイクルエネルギー算定評価システムの開発 Development of the Supporting System of Evaluation of Lifecycle Energy for Promotion of Environmentally Sound Actions
}

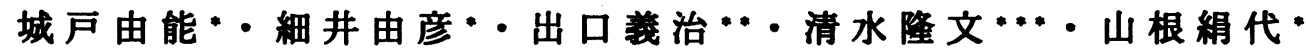 \\ KIDO Yoshinobu ${ }^{*}$, HOSOI Yoshihiko ${ }^{*}$, DEGUCHI Yoshiharu ${ }^{* *}$, SIMIZU Takafumi ${ }^{* * *}$ and YAMANE Kinuyo ${ }^{*}$
}

\begin{abstract}
The purpose of this support system is promoting environmentally sound actions for individuals and groups. The main concept of this system is that more suitable actions presented to people considering their different characters is more feasible for the reduction of environmental dependence. The evaluation of Life-Cycle Energy (LCE) is basically calculated by using unit-load-factor value and frame-data set along the designed lifecycle. In this paper, it is focused that the evaluation of LCE of domestic appliances increased and/or decreased by selected behavior of user. Especially daily actions on utilization of these appliances are estimated high performance on reduction of LCE. Personal Computer System, which is equipped with hierarchical information supplying functions by the window system can be available for promotion of such environmentally sound actions .
\end{abstract}

KEYWORDS : Lyfecycle Assessment (LCA), Lyfecycle Energy(LCE), Environmental Sound Actions, Decision Support System, Environmental Education and Learning

\section{1 .はじめに}

近年の産業・工業社会は大量生産、大量消費、大量廃棄を促進し、その社会構造が産み 出す膨大な環境負荷が地球環境的に問題になっている。特に地球温暧化現象の一因となる 二酸化炭素排出とエネルギー消費の削減のために、国が策定した地球温暖化防止計画にお いても、生活者ひとりひとりの家庭生活の中で無駄な資源・エネルギ一を消費しないとい う環境を配慮したライフスタイルが必要であると考えられている（環境庁,1989他）。し かし、我々の日常生活が環境に与えている影響を正確かつ身近なものとして認識すること は困難であり、ライフスタイルの見直しやその変更がどの程度環境への配慮につながるか も見通し難い。そのため、生活者自身が自らのライフスタイルを診断するためのシステム の提案と開発がこれまでにも行われてきた（盛岡，1992\&1996、和田,1994\&1996）。

本研究では生活者の日常生活において意識にのぼりにくい環境負荷を算定評価する指標 としてライフサイクルエネルギー (LCE)を用い、環境教育・環境学習の機能に着目したシ ナリオに基ついて代表的な家電製品の使用等の生活行動とその変更によるLCE量の増減を 算定して、それをビジュアルな画面構成で視覚的にシステム使用者に提供することで、環 境に配慮したライフスタイルへの変更を支援するシステムの開発を行う。

\section{2.ライフサイクルエネルギー算定の枠組み}

ライフサイクルエネルギー（ LCE）とは、製品やサービスの製造・流通・廃棄等が環境 や資源に与える負荷を資源の採取、素材 ・材料の製造、製品の加工・生産、流通、使用 ・ 消費、廃棄・リサイクルの各段階で消費される全エネルギー量で定量評価するものである。 本研究では、まず、素材生産から廃棄までの財のライフサイクルを設定し（図1）、この 流れに沿って原単位積上げ型の算定式に基ついて代表財の LCE 算定を行った（表 1 ）。 
さらに、財の使用期間の延命効果が評価できるように、各財の間接消費エネルギ一を平均 使用年数で除して 1 年間あたりとし、直接使用エネルギーを合わせて年間 LCE (A-LCE) と して、本システムの算定指標の基本とした。年間 LCE 算定をおこなった家庭内で使用・消 費される代表的な財として、直接エネルギーの占める割合が大きく、使用の工夫に幅のあ る家電製品（5 種）と間接エネルギーを主とする水および紙製品（４種）について試算を おこなっている（表 2、城戸,1994）。なお、水については素材生産および使用過程での 消費エネルギーを無視し、上下水道システムの施設建設に投入された間接エネルギーと処 理運用にかかる直接エネルギーを算出し、それぞれの行程での原単位を合計して単位水量 あたりの LCE 原単位を求め、平均的な一家庭での使用水量を乗じて求めている。また、紙 製品については使用過程での消費エネルギーを無視した以外は表 1 と同様の基本式を用い、 それぞれの紙製品の一家庭での年間消費量に基ついて求めている（（社）資源協会,1994）。 次に、各種文献（環境庁,1987他）で提案されている環境配慮行動を基にして、算定対象 とする生活行動を抽出し、その行動変更を表わす入力変数を設定することでLCE算定に反 映させた（表 3 ）。入力変数の一部が後述の環境配虑行動の効果を算定するための操作変 数であり、行動のエ夫を表現する。

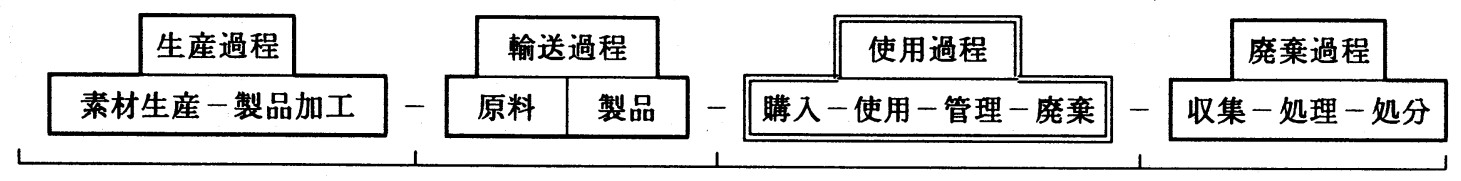

図 1 財のライフサイクル概念図

表 1 LCE 財の年間 LCE 算定式の基本構造

\begin{tabular}{|c|c|}
\hline (1)素材生産 & 素材別重量別生産エネルギー原単位 $(\mathbf{I} \mathrm{cal} / \mathrm{kg}) \times$ 機器構成素材別重量 $(\mathrm{kg})$ \\
\hline (2) 成形加工 & 電気機械器具製造業生産金額あたりエネルギー消費量 $(\mathrm{kcal} / ¥) \times$ 機器別平均生産価格(¥) \\
\hline (3)輸送過程 & 輸送重量あたりトラック輸送原単位 $(\mathrm{kcal} / \mathrm{kg} \cdot \mathrm{km}) \times$ 平均輸送距離 $(\mathrm{km}) \times$ 輸送重量 $(\mathrm{kg})$ \\
\hline (4)使用過程 & 標準仕様での財別使用エネルギー原単位 (kcal/時間) $\times$ 使用時間(時間) $\times$ 実効率 (\%) \\
\hline (5)廃棄 · 処理 & 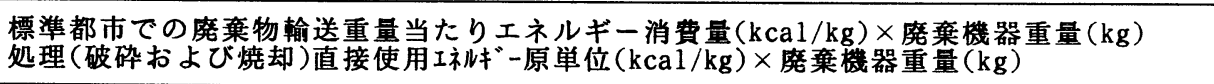 \\
\hline (6)使用年数 & 財別標準使用年数 \\
\hline
\end{tabular}

表 2 各種家庭剘の年間 LCE の試算例

\begin{tabular}{|l|l|r|}
\hline \multicolumn{2}{|l|}{ 家庭内使用財 } & 年間 LCE \\
\hline \multirow{3}{*}{} & テレビジョン & $458.8^{(* 1)}$ \\
\cline { 2 - 3 } & 冷蔵庫 & $804.4^{(* 1)}$ \\
\cline { 2 - 3 } & 洗濯機 & $193.8^{(* 1)}$ \\
\hline & エアコンディショナー & $3509.4^{(* 1)}$ \\
\hline & 掃除機 & $62.3^{(* 1)}$ \\
\hline
\end{tabular}

\begin{tabular}{|l|l|c|}
\hline \multicolumn{2}{|l|}{ 家庭内使用財 } & 年間 LCE \\
\hline & 使用水道水 & $1700.8^{(* 2)}$ \\
\hline \multirow{2}{*}{} & 書籍 & $373.5^{(* 2)}$ \\
\cline { 2 - 3 } & 新聞 & $801.0^{(* 2)}$ \\
\cline { 2 - 3 } & ティッシュペーパー & $192.4^{(* 2)}$ \\
\cline { 2 - 3 } & トイレットペーパー & $296.5^{(* 2)}$ \\
\hline
\end{tabular}

*1:(Mcal/Yearunit), *2:(Mcal/YearHouse)

表 3 環境配慮行動と LCE 算定評価のための入力変数の例

\begin{tabular}{|l|l|}
\hline 対象財 & LCE算定のための入力変数の例 \\
\hline テレビジョン & 型式、台数、視聴時間/非視聴時間、主電源、画面の輝度、ボリューム、他 \\
\hline 冷蔵庫 & 型式、台数、設置場所、設定温度、庫内品の量、ドア開閉回数、他 \\
\hline 洗濯機 & 型式、台数、全自動 $/$ 層式、洗濯コース内容設定、風呂残り湯利用、他 \\
\hline エアコンディショナー & 型式、台数、室外機設置場所、冷暖房設定温度、エアフィルタ清掃、他 \\
\hline
\end{tabular}




\section{3 .本システムの特散}

本システムの基本構造は、被験者とのインターフェイス部分と生活行動に関連する LCE 算定フレームおよびこの両者を統括するシステム運用シナリオから構成される（図 2 ）。 被験者とのインターフェイス部分は、生活行動を入力するインターフェイスと個別の行動 変更もしくはその集積としての LCE 量の数值そのもの（ Mcal 年など）とその增減（％) を視覚的に表示するインターフェイスからなり、LCE 算定フレームは、財の LCE 基本算定 式を基にした簡便な計算モジュールからなる。

本システムの特徵のひとつは、市民の環境に配虑した行動選択を支嗳するために、環境 教育 ・環境学習の基本要件の中から特に「関心・知識・技能・行動」の 4 つの要件に着目 したシナリオを設定し（盛岡,1990）、システムの運用を図ることであり、具体的には 3 つのシナリオと 2 つサブシナリオから構成される。以下に各シナリオの内容を示す。

シナリオA（ものから見た暮らしの診断）は、家庭生活において身近な財であり、LCE 削滅の方法が多数ある家電製品について被験者が所有台数やその型式などについての $5 つ$ 程度の質問項目に対話式に答えることにより、各財の年間 LCE 即座に算定し、その結果 を表示する(図4）。このシナリオでは、引き続いて行動内容を一部変更して入力するこ とで、行動変更による年間 LCE の増減を比較することが可能であり、直接／間接別の年間 LCE 量そのものに加えて原油・金銭換算等の数值的な表示とともに、前回との比較を顔の 表情などに加エして情報提供する（図 5 ）。

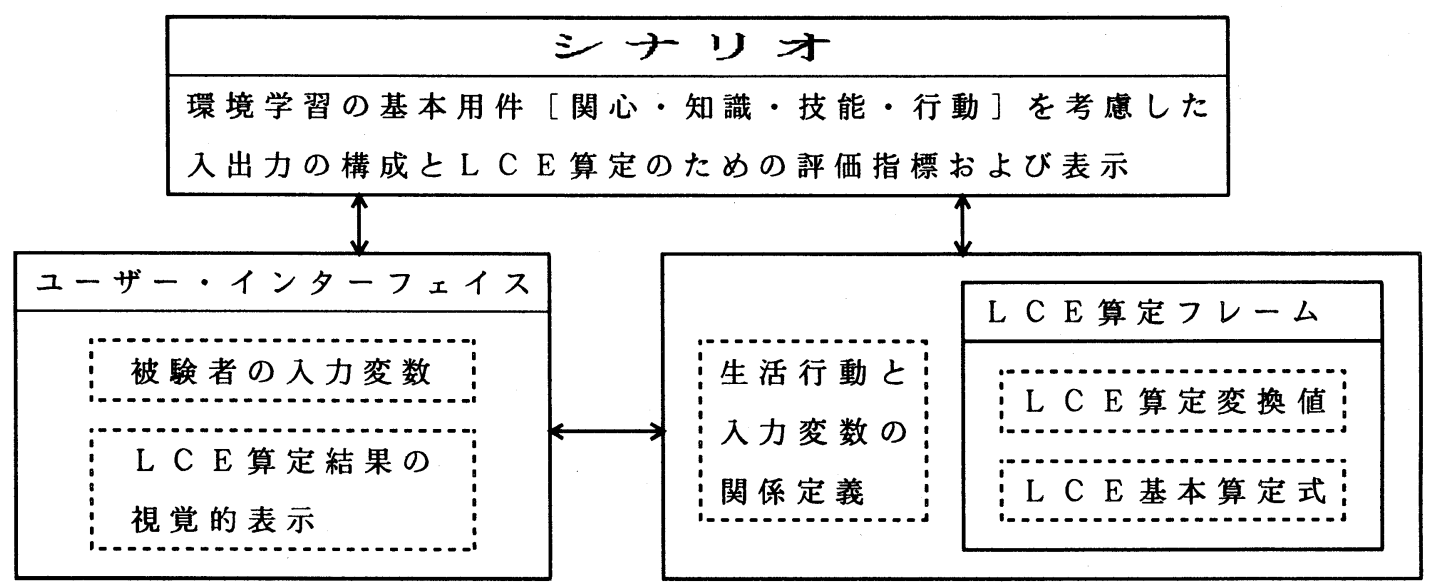

図 2 LCE 算定評価システムの全体構造

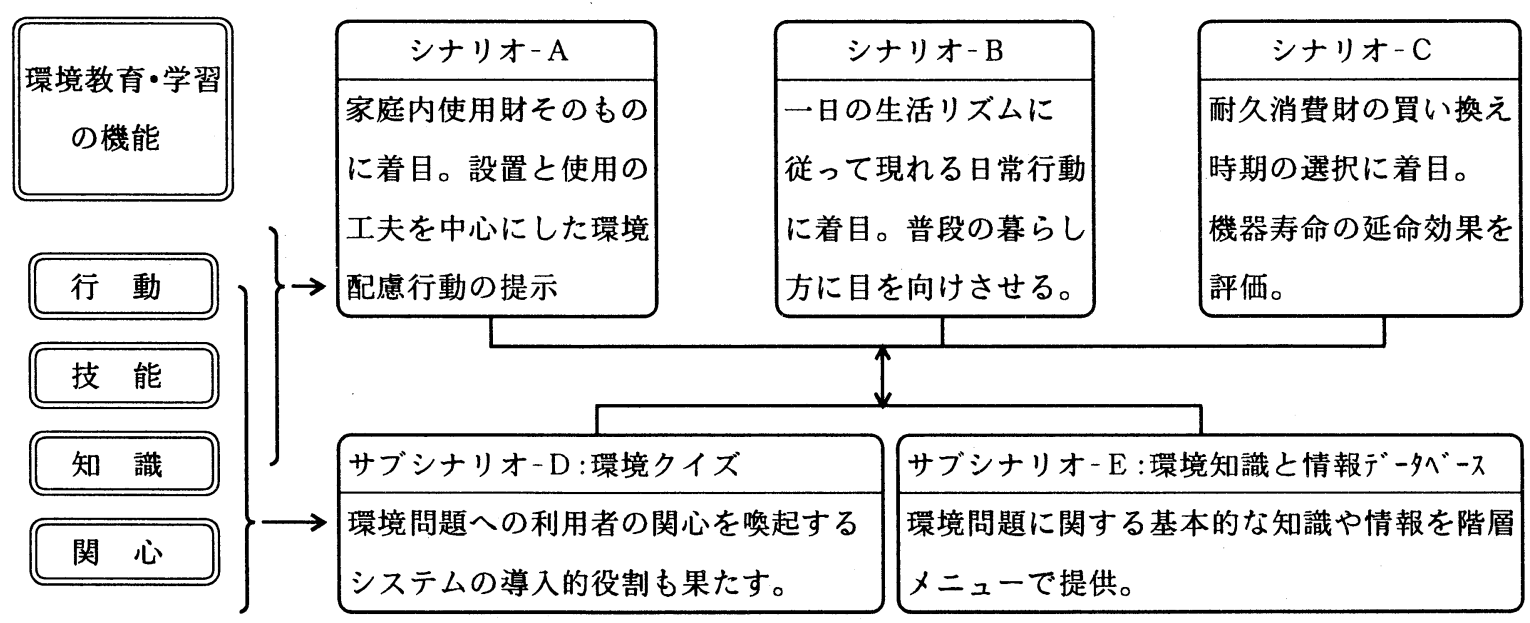

図 3 環境教育・学習機能を重視したシナリオ構成 


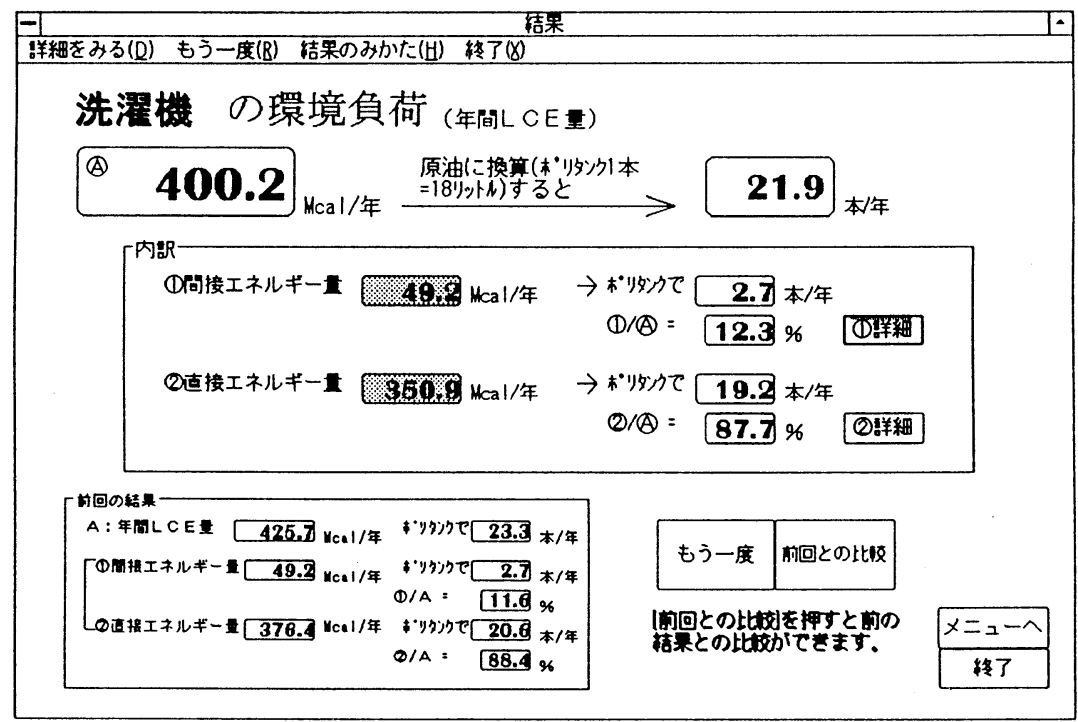

図 4 シナリオ A 洗濯機の年間 LCE 算定結果の画面例

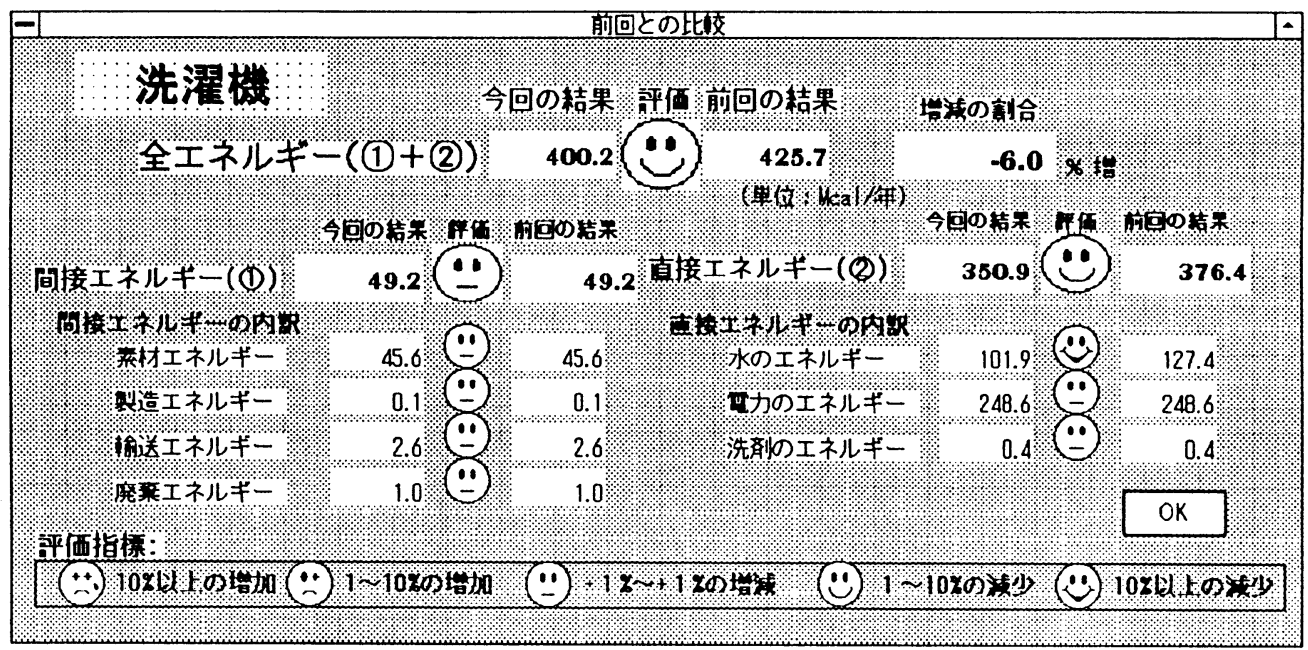

図 5 シナリオ A 環境に配虑した行動変更の前後での LCE 算定評価画面例

シナリオ B ( 1 日の生活行動と環境負荷)では、1 日の朝起きてから夜寑るまでの平均 的な 1 日の生活の時間的推移に従って、装置性の有る財/無い財に関する $5 つ$ 程度の行動 が提示され、その行動内容の選択肢に答えることに基ついて、初期状態でのLCEを算定す る。表示された現状の LCEに対して、被験者自ら削減目標を入力し、それを達成するまで 行動変更が選択される。設問に回答することにより日常生活の時間的な流れに潜むLCE 消 費に被験者の関心を向けさせるねらいをもつ。

シナリオC（環境負荷から見たものの買い換え）では、現在、所有している財の使用期 間の延長と最新の省エネ、省資源型製品への買い換えを、設定した一定期間の使用を前提 にして LCE 面から評価する。直接エネルギーの割合の高い家電製品では、特に、旧式の消 費電力の高い機器を使い続けるよりも新たな省エネ機器を購入することの効果が現れやす い。ただし、本質的な環境負荷を相対として議論する上では、資源そのものの消費や廃棄 による土地の損失など LCE 以外の側面からの評価と総合して考える必要がある。

シナリオ $\mathrm{A} \sim \mathrm{C}$ の流れとシステム内部での関連およびテータの流れを図 6 に示す。表 4 には各シナリオでの行動変更による削減効果の試算例を示している。 


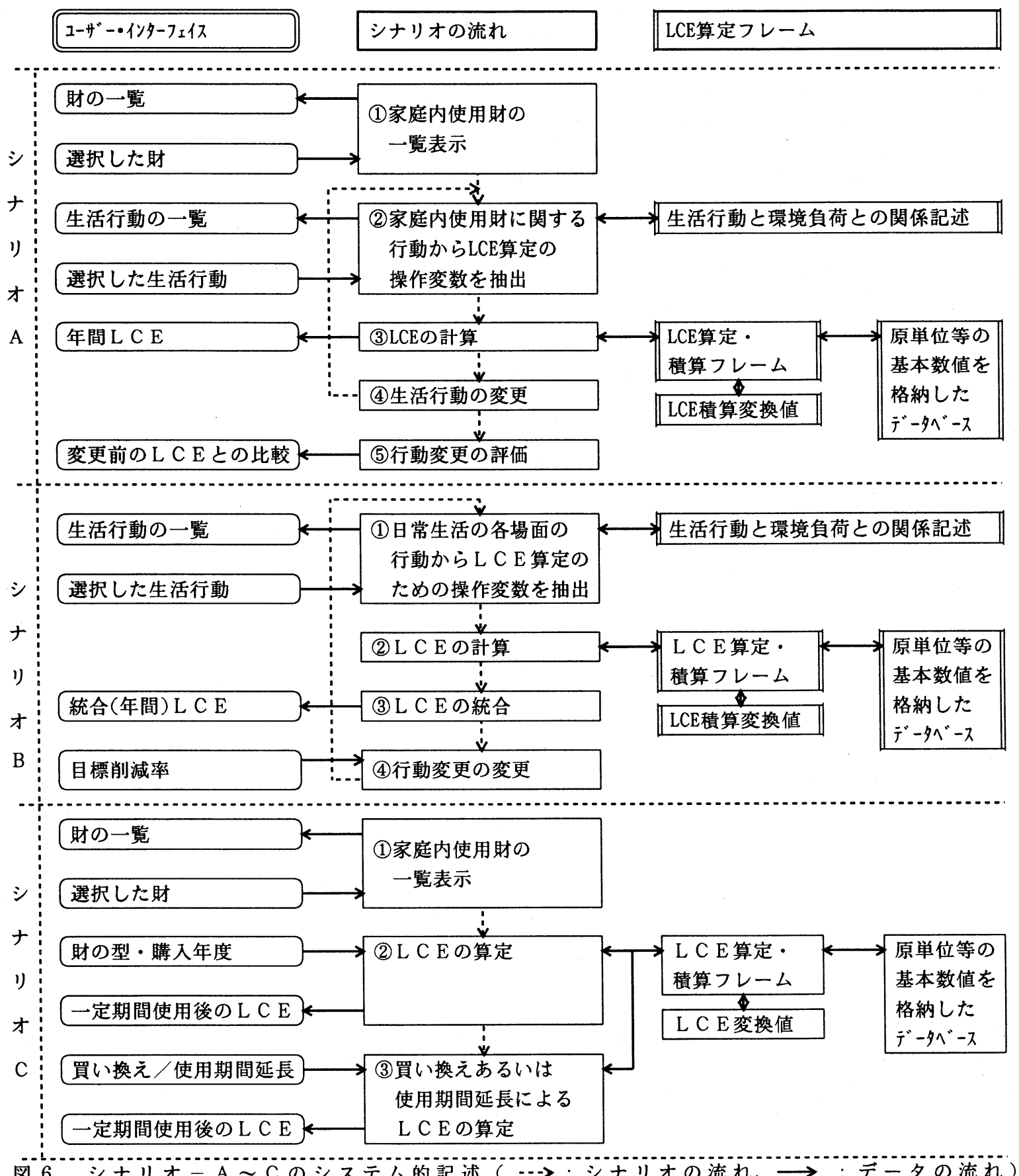

表 4 行動の工夫と年間 LCE 削減効果

\begin{tabular}{|c|c|c|c|}
\hline シナリオ & 財 & 生活行動の変更 & $\begin{array}{c}\text { 年間 L C C E の } \\
\text { 削減率 }\end{array}$ \\
\hline シナリオ $\mathrm{A}$ & テレビ & 視聴時間の短縮 $6 \mathrm{~h} \mathrm{r} \rightarrow 5 \mathrm{~h} \mathrm{r}$ & $15.4 \%$ \\
\hline シナリオ B & アルミ缶 & 1 日での購入 2 本 $\rightarrow 1$ 本 & $17.0 \%{ }^{2)}$ \\
\hline シナリオC & 冷蔵庫 & $\begin{array}{l}\text { 購入時(81年, } 170 \mathrm{~L}) \\
\text { 買い換えないい買い換える(85年, 170L) }\end{array}$ & $20.8 \%{ }^{3)}$ \\
\hline
\end{tabular}

1): テレビ 1 台に対する削減率 ,2): 被験者が選択した 5 つの行動に対する削減率,3): 使用総期間 15 年を仮定 
サブシナリオ D（環境クイズ）では環境関連図書（環境庁,1989他）から日常生活と環 境との関りについて整理したものを、3 択ないし 5 択式のクイズ形式を用いて被験者に情 報提供するシナリオであり、1 回の試行でテータベースから 5 問がランダムに選ばれ、そ の出典とともに提示され、回答と正解の表示がおこなわれる。最終的な正答率が表示され るとともに、次のサブシナリオ $\mathrm{E} へ の$ 誘導をおこなう。環境に関する一般的な関心の喚起、 知識取得の動機つけを目的とし、被験者に対し、本システムの導入的役割を果たす。

サブシナリオ $\mathrm{E}$ (環境負荷に関する豆知識) では、水やエネルギーなどの 5 つの分野に ついて、環境問題関連書籍（環境庁,1989他）等から抜粋した環境の現況、環境負荷の削 減方法など情報を階層的メニューに従って情報提供するとともに、本システムで取り上げ た内容についての解説の役割を果たす、。ここでも、出典を明示することで、ユ一ザーが より詳しい内容にたどりつけるよう配虑している。

\section{4 .まとめ}

操作性の優れたパソコンで動作するシステムの開発を行い、試作版の運用評価をおこな った。典形式は解説パネルとパソコン 2 台を設置し、インストラクターを配置して被験者 に対する操作説明やテモンストレーションを実施した。被験者には、システム利用後に画 面の構成や用語の不明点、システム利用前後での環境配虑に関する意識などについての簡 単なアンケートに回答してもらった。その結果を踏まえて、表示文字の拡大や数值加工の 工夫などの情報提供機能面での改善と、用語説明やシステム操作説明用の呼び出し副画面 を作成するなどのいくつかの改良をはかった。また、システム利用の前後での環境に配慮 した行動変更に対する意識の高まりが確認された。

今後は、単体システムとしての運用おょび機能改善を継続するとともに、コンピュー夕 ネットワークを利用した広域の主体へのシステム提供と情報交流を支嗳するシステムへの 発展を検討中である。また、環境に配慮した生活行動変更への支援として、ユ一ザ一の性 格やライフスタイルの多様性に配慮した評価（城戸，1994）を加えること、および長期的 なシステムの運用を通してユーザーの環境観を形成するような環境教育・環境学習的機能 を加えていくことが課題として挙げられる。

謝 辞: 本研究の一部は平成6年度文部省科学研究費重点領域研究人間地球系」(課題番号06271243)の補助を受けたことを記して謝意を表す。 なお、本システムの構築に用いた、Windows および Visual Basic は米国マイクロソフト社の商標です。

\section{参考文献}

1) 環境庁 (1989)：地球にやさしい暮らしの工夫,大藏省印刷局 , 他多数の書籍と資料 .

2) 城戸由能, 細井由彦, 他 (1996)：ライフサイクルエネルギーの算定に基づく環境配虑行動評価システムの開発, 環 境科学会 1996 年会講演概要集, (印刷中).

3) 城戸由能, 細井由彦, 他 (1994)：財のライフサイクルエネルギーに基つく環境配慮行動評価に関する研究, 土 木学会第 50 回年次講演会講演集,Vol. II ,pp.956-957.

4) 通商産業大臣官房調查統計部編：鉄鋼統計年報 (1992), 石油等消費動態統計調查 (1991), 産業別燃料消費統計 (1990), エネルギー生産・受給統計年報 (1994), 他各種統計資料 .

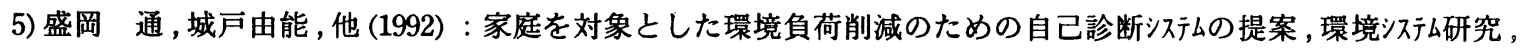
Vol.20,pp.184-189.

6) 盛岡 通 (1996)：環境負荷を家計単位で勘定する意義と方法, システム/制御 / 情報, Vol.40, No.3, pp.93-100 7)(社) 資源協会編 (1994)：家庭生活のライフサイクルエネルギー,(株) あんほるめ。

8)SETC\&SETAC(1991):A Technical Framework for Life-Cycle Assessments, SETAC Foundation.

9)SETC\&SETAC(1993):A Conceptual Framework for Life-Cycle Impact Assessment, SETAC Foundation.

10)和田安彦,三浦浩之, 他 : ライフスタイル自己診断システムの開発と評価, 環境システム研究,Vol.22,pp.300-305.

11) 和田安彦 (1996)：ライフスタイル自己診断システムの開発と評価の適用, システム/制御/情報,Vol.40, No.3, pp.101- 107 . 